METALLURGY AND FOUNDRY ENGINEERING - Vol. 35, 2009, No. 2

Janusz Krawczyk*, Jerzy Pacyna**

\title{
EFFECT OF THE COOLING RATE ON THE MOTTLED CAST IRON MICROSTRUCTURE DESIGNED FOR THE MILL ROLLS
}

\section{INTRODUCTION}

High requirements set for mill rolls applied for hot a plastic working of steel incline for searching for new materials or modifications of the already used ones. One of such materials is alloy mottled cast iron, spheroidal, chromium-nickel GJS-HV300(SiCrNi2-3) [1-6]. This material of a pearlite-bainitic matrix found an application, among others, for mill rolls in hot mills in the finishing stands group [1, 2]. It meets the expectations of users of mill rolls in hot mills in the scope of its hardness and abrasion resistance. However, the basic shortcoming of this cast iron is its relatively high price (on account of $3.5 \%$ of nickel) as well as a very small crack resistance, especially important in the case of rolls used in shape mills. Due to this, there are problems in applying this cast steel e.g. for rolls applied for rolling technologically difficult profiles, such as railway rails and channel bars. An improvement of a crack resistance of this material can be achieved by the adequate heat treatment [7-9].

Apart from the determination of the transformation kinetics of overcooled austenite [10], an estimation of the effect of the cooling rate - in the austenitic range - on the volume fraction of carbide phases and graphite is necessary for designing the optimal heat treatment.

The determination of the influence of the heat treatment on the microstructure of cast iron GJS-HV300(SiCrNi2-3) was the aim of the present paper (according to the rules: PN-EN).

\section{TEST MATERIAL}

Test material constituted a chromium-nickel mottled nodular cast iron GJS-HV300 (SiNiCr2-3). Chemical composition of the investigated cast iron is presented in Table 1. The

* Ph.D., **Prof. D.Sc., Ph.D., Faculty of Metals Engineering and Industrial Computer Science, AGH - University of Science and Technology, Kraków, Poland; e-mail: jkrawczy@metal.agh.edu.pl 
microstructure in as-delivered condition is shown in Figure 1. Test material was sampled from the cast roll delivered by the manufacturer.

One may see that, this is mottled cast iron with the pearlite-bainitic matrix (with upper bainite). It is characterized by a high content of ledeburitic cementite (with adjoined hypereutectoid cementite), which creates a continuous network.

Table 1. Chemical composition (weight \%) of the investigated GJS-HV300(SiNiCr2-3) cast iron

\begin{tabular}{|c|c|c|c|c|c|c|c||}
\hline \hline $\mathrm{C}$ & $\mathrm{Mn}$ & $\mathrm{Si}$ & $\mathrm{P}$ & $\mathrm{S}$ & $\mathrm{Cr}$ & $\mathrm{Ni}$ & $\mathrm{Mo}$ \\
\hline 3.2 & 0.52 & 2.24 & 0.07 & 0.012 & 0.53 & 3.49 & 0.56 \\
\hline $\mathrm{Mg}$ & $\mathrm{Cu}$ & $\mathrm{Al}$ & $\mathrm{Ti}$ & $\mathrm{V}$ & $\mathrm{As}$ & $\mathrm{Nb}$ & $\mathrm{Fe}$ \\
\hline 0.047 & 0.20 & 0.008 & 0.014 & 0.020 & 0.002 & 0.024 & bal. \\
\hline
\end{tabular}

a)

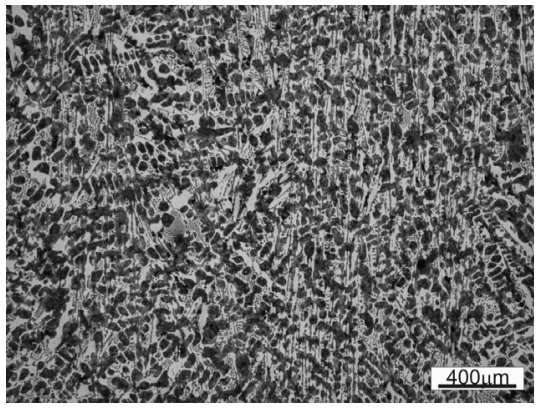

c)

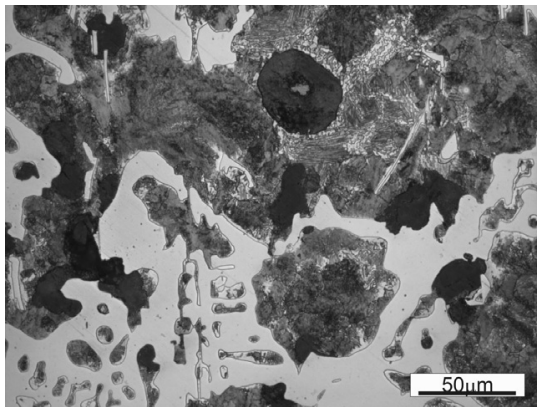

b)

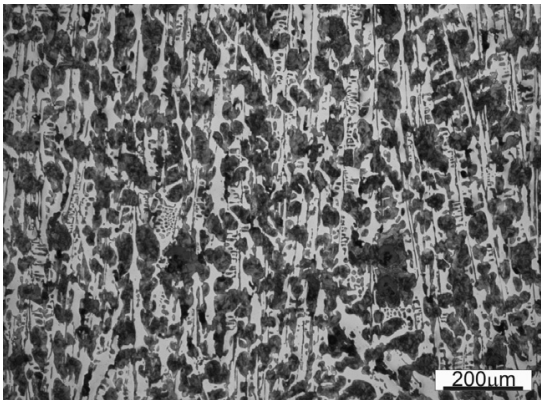

d)

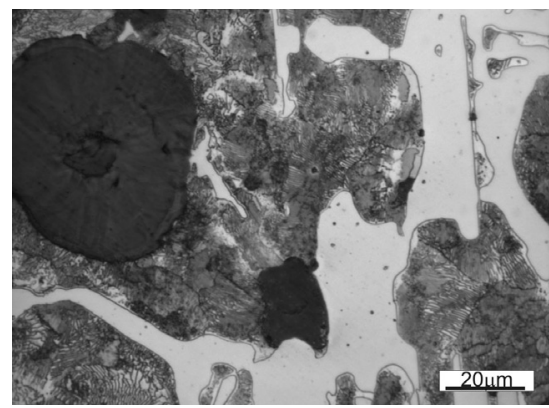

Fig. 1. Microstructure of the investigated cast iron (in as-delivered condition): a) ledeburite morphology; b) ledeburitic cementite morphology; c) graphite morphology; d) matrix microstructure. Etched with $2 \%$ nital

\section{HEAT TREATMENT}

Modification of the investigated cast iron microstructure was carried out by the heat treatment. Five variants of the heat treatment were performed diversified by the cooling rate. Austenitizing temperature was $950^{\circ} \mathrm{C}$. The temperature was selected on the basis of the 
research presented in studies $[9,10]$, as well as so as to comply with the technological potential of the mill rolls manufacturers and to ensure the highest possible solubility of ledeburitic cementite (with adjoined hypereutectoid cementite) in an austenitic matrix.

Variant I of the heat treatment was characterised by slow cooling $\left(12^{\circ} \mathrm{C} / \mathrm{h}\right)$ within the range of austenite occurrence (down to a temperature of $700^{\circ} \mathrm{C}$ ). Further cooling was performed in such a way as to ensure the pearlitic matrix formation $\left(18^{\circ} \mathrm{C} / \mathrm{h}\right)$.

Variant II of the heat treatment was characterised by slow cooling $\left(12^{\circ} \mathrm{C} / \mathrm{h}\right)$ to a temperature of $780^{\circ} \mathrm{C}$ followed by a fast cooling $\left(45^{\circ} \mathrm{C} / \mathrm{h}\right)$ to a temperature of $700^{\circ} \mathrm{C}$. Further cooling was performed in such a way as to ensure the pearlitic matrix formation $\left(18^{\circ} \mathrm{C} / \mathrm{h}\right)$.

Variant III of the heat treatment was characterised by fast cooling $\left(45^{\circ} \mathrm{C} / \mathrm{h}\right)$ within the range of austenite occurrence (to a temperature of $700^{\circ} \mathrm{C}$ ). Further cooling was performed in such a way as to ensure the pearlitic matrix formation $\left(18^{\circ} \mathrm{C} / \mathrm{h}\right)$.

Variant IV of the heat treatment was characterised by slow cooling $\left(12^{\circ} \mathrm{C} / \mathrm{h}\right)$ within the range of austenite occurrence (to a temperature of $700^{\circ} \mathrm{C}$ ). Further cooling was performed in such a way as to ensure the bainitic matrix formation $\left(216^{\circ} \mathrm{C} / \mathrm{h}\right)$.

Variant $\mathrm{V}$ of the heat treatment was characterised by fast cooling $\left(45^{\circ} \mathrm{C} / \mathrm{h}\right)$ within the range of austenite occurrence (to a temperature of $700^{\circ} \mathrm{C}$ ). Further cooling was performed in such a way as to ensure the bainitic matrix formation $\left(216^{\circ} \mathrm{C} / \mathrm{h}\right)$.

\section{THE RESULTS OF THE MICROSTRUCTURE INVESTIGATIONS AFTER THE HEAT TREATMENT AND THEIR DISCUSSION}

The applied heat treatments caused significant changes in the microstructure of the investigated cast iron. The microstructures obtained after the individual variants of the heat treatment are presented in Figures 2-6.

The heat treatment, regardless of the applied variant, caused a clearly visible fragmentation of lederburitic cementite precipitates as well as a significant decrease of its participation in a cast iron volume. An increase of graphite precipitates as well as an increase of its participation in a cast iron volume can be also seen after the heat treatment.

a)

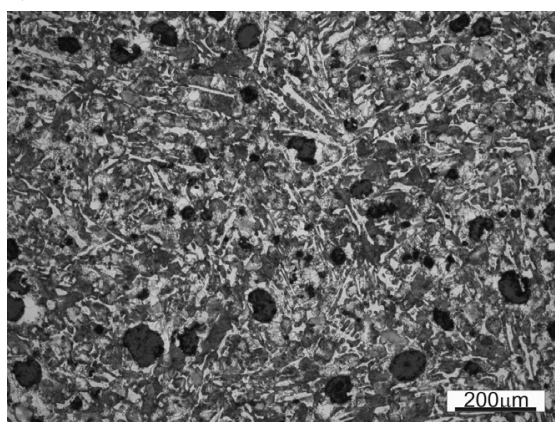

b)

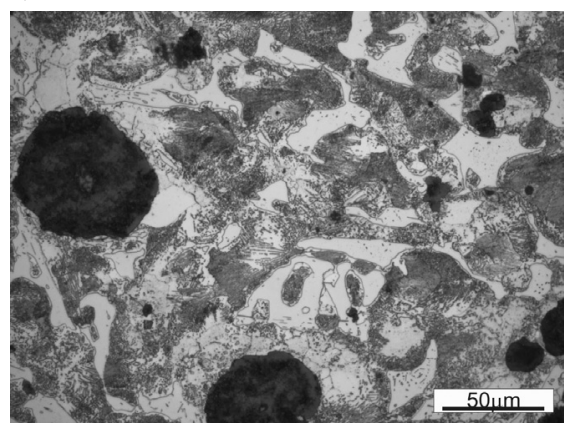

Fig. 2. Microstructure of the investigated cast iron after variant I of the heat treatment: a) ledeburitic cementite and graphite morphology; b) matrix microstructure. Etched with $2 \%$ nital 
a)

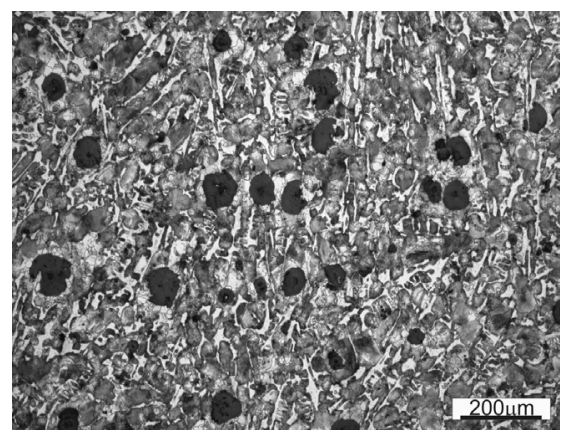

b)

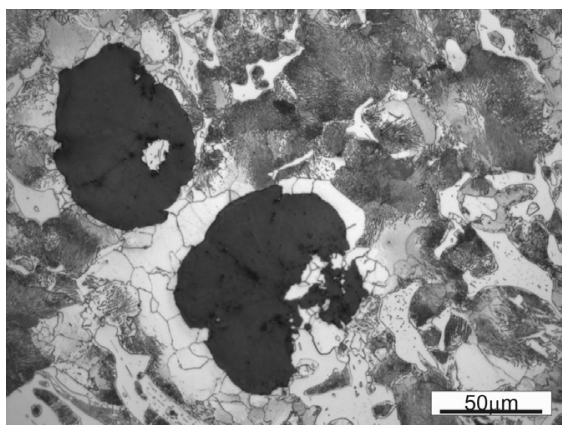

Fig. 3. Microstructure of the investigated cast iron after variant II of the heat treatment: a) ledeburitic cementite and graphite morphology; b) matrix microstructure. Etched with $2 \%$ nital

a)

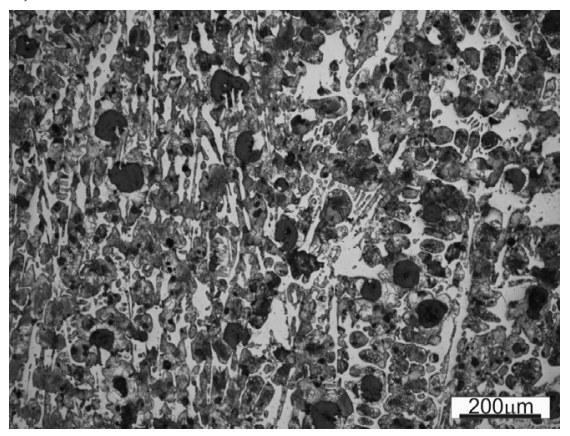

b)

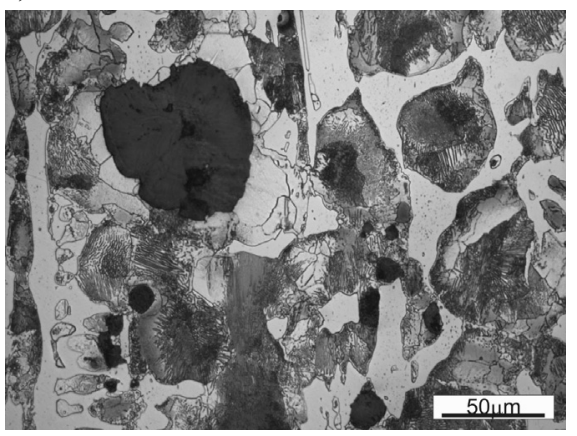

Fig. 4. Microstructure of the investigated cast iron after variant III of the heat treatment: a) ledeburitic cementite and graphite morphology; b) matrix microstructure. Etched with $2 \%$ nital

a)

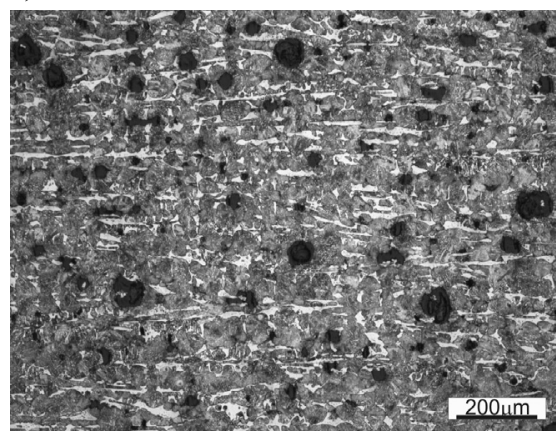

b)

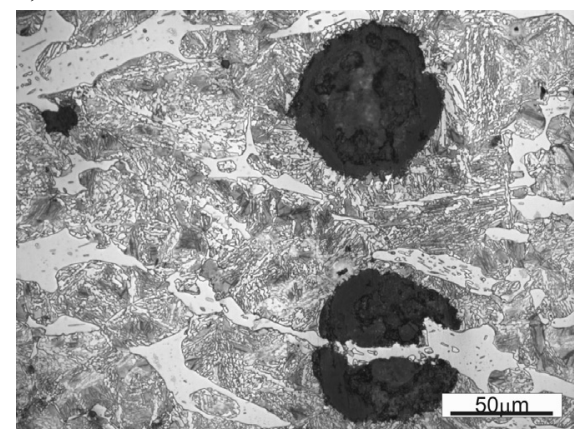

Fig. 5. Microstructure of the investigated cast iron after variant $I V$ of the heat treatment: a) ledeburitic cementite and graphite morphology; b) matrix microstructure. Etched with $2 \%$ nital 
a)

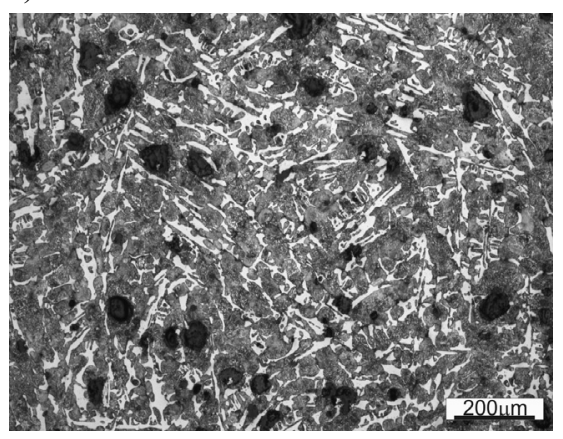

b)

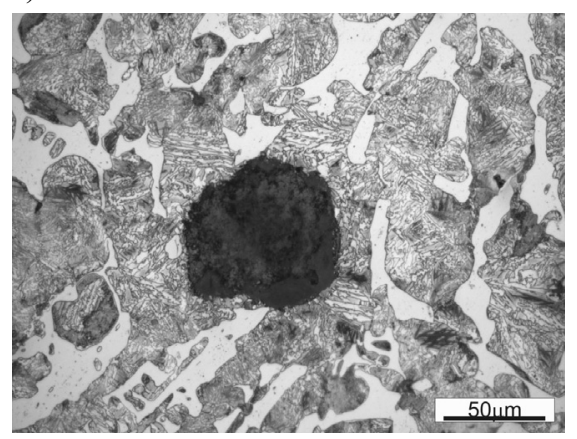

Fig. 6. Microstructure of the investigated cast iron after variant $V$ of the heat treatment: a) ledeburitic cementite and graphite morphology; b) matrix microstructure. Etched with $2 \%$ nital

The cooling rate selection during the heat treatment based on the CCT diagrams within the eutectoidal transformation allowed to obtain the desired (expected) structure of the matrix. As can be seen in microphotographs presented in Figures 2a, 3a, 4a, 5a and 6a the pearlitic matrix was obtained in the case of variants I-III, while the bainitic matrix in the case of variants IV-V.

The bainitic microstructure pattern in the matrix of the investigated cast iron after the heat treatment, obtained by means of the confocal microscope, is presented in Figure 7.

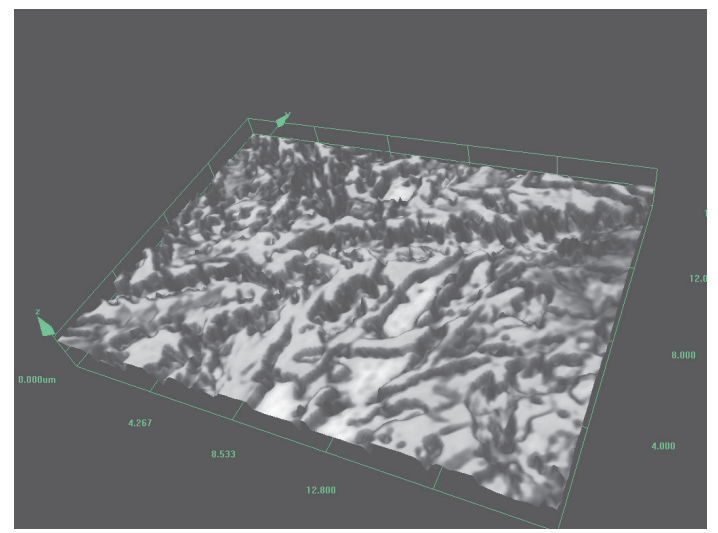

Fig. 7. Microstructure of the bainitic matrix. Confocal microscope

A stereological analysis of volume fractions of structural components $\left(\mathrm{V}_{\mathrm{V}}\right)$ was performed by means of the point method, with the application of a network deposited on the microstructure photographs. For each variant of the heat treatment 30 depositions of the network were performed. Measurements were done on microphotographs obtained by using an objective of 50 times magnification. The network with 200 measurement points was applied. 
The graphical presentations of the volume fraction of individual elements of the microstructure for the initial state and for the respective variants of the heat treatment are shown in Figures 8-13. Standard deviations are also marked in these diagrams.

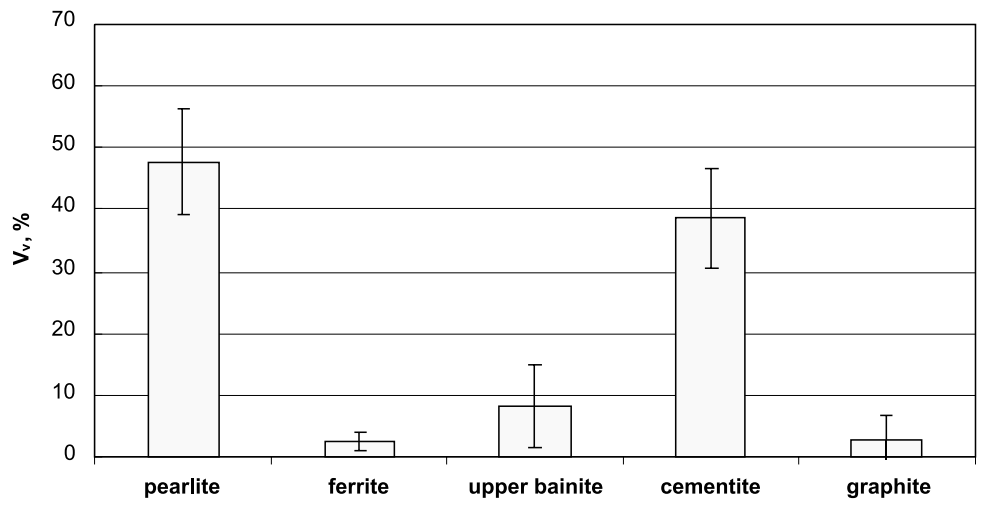

Fig. 8. Presentation of the volume fraction of individual microstructure elements of the investigated cast iron for as-delivered condition

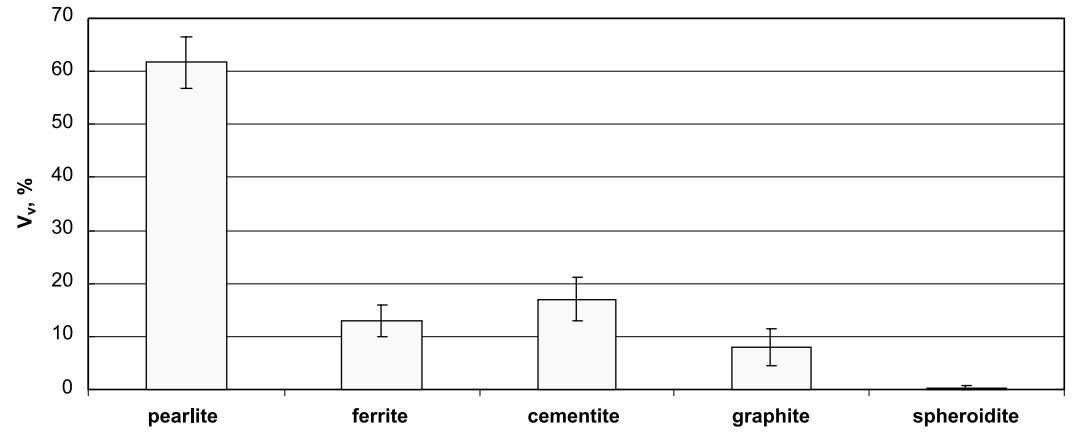

Fig. 9. Presentation of the volume fraction of individual microstructure elements of the investigated cast iron for variant I of the heat treatment

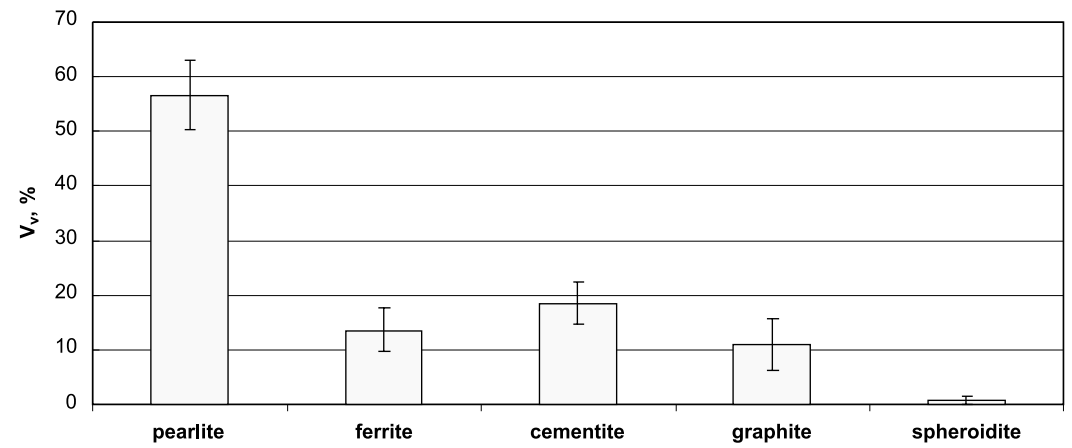

Fig. 10. Presentation of the volume fraction of individual microstructure elements of the investigated cast iron for variant II of the heat treatment 


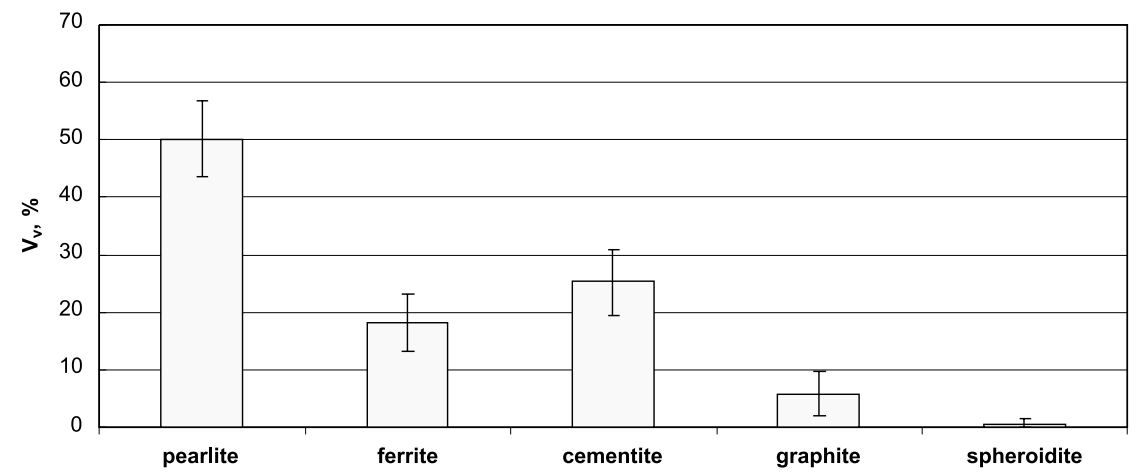

Fig. 11. Presentation of the volume fraction of individual microstructure elements of the investigated cast iron for variant III of the heat treatment

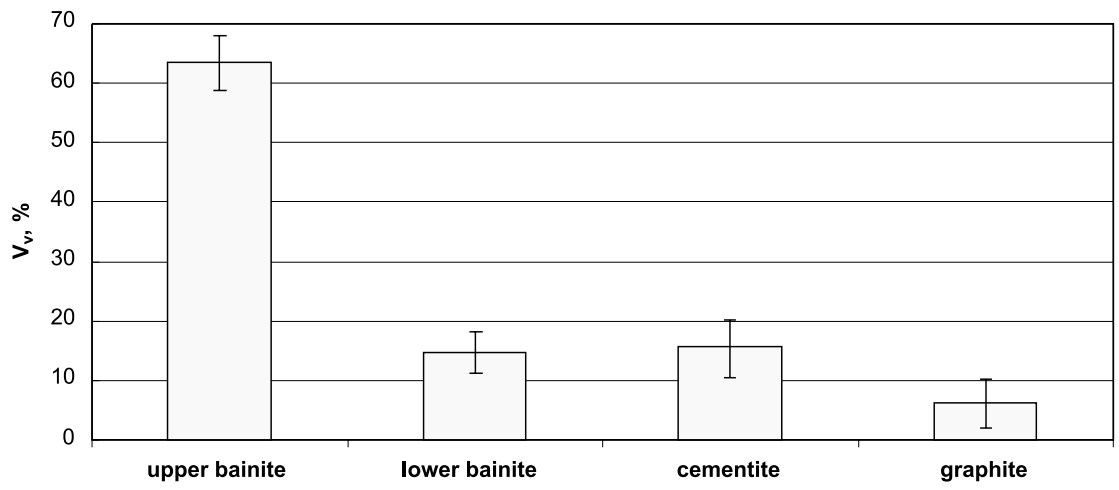

Fig. 12. Presentation of the volume fraction of individual microstructure elements of the investigated cast iron for variant $I V$ of the heat treatment

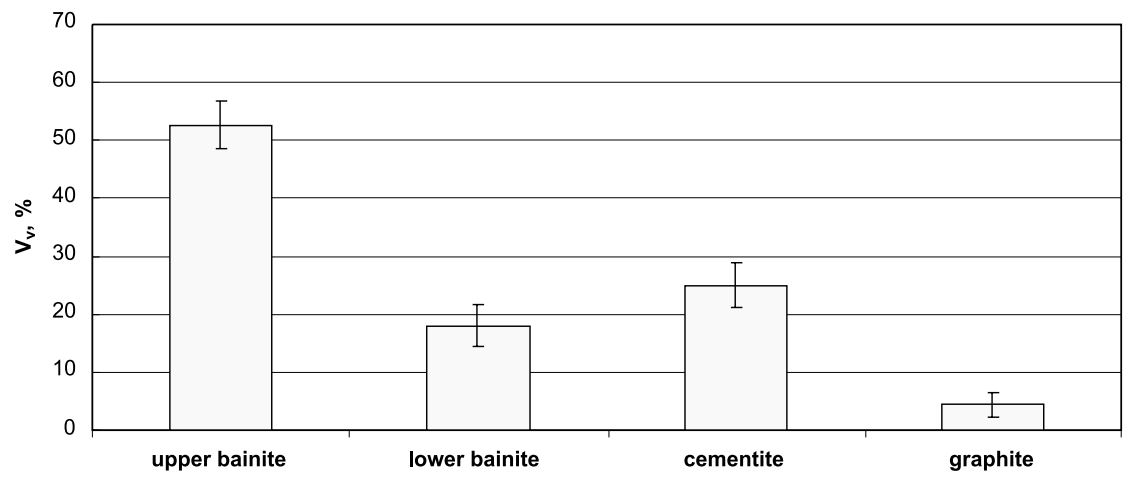

Fig. 13. Presentation of the volume fraction of individual microstructure elements of the investigated cast iron for variant $V$ of the heat treatment 
Analysing the cast iron microstructure, after the heat treatment performed in such a way as to obtain the pearlitic matrix (variants I, II and III), one can observe that apart from pearlite also ferrite and small amounts of spheroidite are present in the matrix. Spheroidite was absent in the microstructure in as-delivered condition. This occurs due to the fact, that areas in the vicinity of graphite precipitates undergo decarburisation as the result of the carbon diffusion towards graphite. It can be seen that this effect intensifies with the cooling rate increase in the austenitic range. The most probably this is the result of shortening the possible carbon diffusion path in the matrix of the investigated cast iron. The carbon concentration is not equalized in the whole matrix.

In the case of samples heat treated in such a way as to obtain the bainitic structure (variants IV and V) apart from upper bainite also lower bainite was found in the matrix. It can be seen that the volume fraction of lower bainite increases and upper bainite decreases when the cooling rate in the austenitic range increases.

Differences in the cooling rates in the austenitic range influence essentially an amount of lederburitic cementite (with adjoined hypereutectoid cementite).

An increased cooling rate after the heat treatments performed in such a way as to obtain the pearlitic matrix (variants I, II and III) causes the occurrence of larger amounts of lederburitic cementite (with adjoined hypereutectoid cementite) in the microstructure. Similar situation is seen in the case of samples after the heat treatment leading to the bainitic matrix formation (variant IV and V).

It can be also noticed that the amount of lederburitic cementite after each heat treatment is smaller than in as-delivered condition.

An explanation of the above differences requires analysis of changes in a graphite content. After each variant of the heat treatment a graphite content is larger than in as-delivered condition. This indicates that during the heat treatment of cast irons containing graphite a certain part of carbon diffuses to those precipitates causing the matrix to be depleted of carbon and to diminish the amount of ledeburitic cementite. This process intensifies when the cooling rate decreases in the austenitic range. A very large amount of graphite, when the heat treatment of various cooling rates in the austenitic range was applied (variant II), can be caused by the place of sampling as well as by changes in the carbon diffusion path which lead to a small increase of areas of a spheroidal structure.

In a similar fashion, in the case of the heat treatment performed to obtain the bainitic matrix (variant IV and V), it was found that decreasing of the cooling rate in the austenitic range leads to an increase of the graphite amount in the matrix of the investigated cast iron.

\section{CONCLUSIONS}

Investigations performed during this study allow to formulate several conclusions.

- The heat treatment allows changing - in a wide range - the microstructure of the investigated cast iron. 
- Increasing of the graphite amount in the mottled cast iron matrix during the heat treatment (requiring austenitizing) is accompanied by decreasing participation of lederburitic cementite (and adjoined hypereutectoid cementite). The carbon content in the matrix is also diminishing.

- The cooling rate in the austenite range influences volume fractions of cementite and graphite. When the cooling rate is increased more cementite remains in the microstructure while the graphite volume fraction decreases.

- The application of the heat treatment leading to the pearlitic transformation favours an increase of the volume fraction and size of lederburitic cementite as compared with the heat treatment leading to the bainitic matrix formation.

- The application of the heat treatment leading to the pearlitic transformation causes an increase of the graphite volume fraction as compared with the heat treatment leading to the bainitic matrix formation.

\section{Acknowledgements}

The authors would like to thank Mr Dariusz Tyrka and Mr Artur Szopiński for their help in this research.

Project financed by the Ministry of Science and Higher Education, completed under AGH-UST's own research activities no. 10.10.110.855.

\section{REFERENCES}

[1] Pacyna J., Kokosza A., Krawczyk J.: The profiled cast iron rolls wear mechanism, Proc. of the Conf. (Konferencja Naukowo-Techniczna „Kierunki rozwoju produkcji walców”), Wisła-Malinka, Poland, February, 21-23, 2001, 157-168 (in Polish)

[2] Pacyna J., Krawczyk J.: Conditions of formation and properties of the white layer, Metallurgy - Metallurgical Engineering News, Vol. 72, No. 11 (2005) 545-553 (in Polish)

[3] Krawczyk J., Pacyna J.: Effect of tool microstructure on the white layer formation, Journal of Achievements and Manufacturing Engineering, Vol. 17, spec. Iss. 1 (2006) 93-96

[4] Krawczyk J., Pacyna J., Kokosza A.: Fracture toughness of cast materials for mill rolls, Proc. of the $6^{\text {th }}$ Int. Conf. for Mesomechanics (Multiscaling in Applied Science and Emerging Technology - Fundamentals and Applications in Mesomechanics), Patras, Greece, May 31-June 4, 2004, 203-207

[5] Krawczyk J., Pacyna J., Szczygiel A., Latała D.: The role of transformed ledeburite and hypereutectoid cementite morphology on mill roll tribology, Proc. of the Conf. (XI Konferencja Naukowo-Techniczna „Tendencje i kierunki rozwoju produkcji walców”, Huta Buczek Sp. z o.o.), Ustroń - Jaszowiec, Poland, March, 2006, 53-66 (in Polish)

[6] Pacyna J., Krawczyk J.: The influence of heat treatment on transformed ledeburite morphology in hypoeutectic alloys, Proc. of the 10th Jubilee Int. Sc. Conf. (Achievements in Mechanical \& Materials Engineering), Gliwice-Kraków-Zakopane, Poland, December, 9-13, 2001, 429-434 (in Polish)

[7] Pacyna J., Krawczyk J., Zajac G.: The new heat treatment technology of spheroidal chromium-nickel cast iron, Metalurgia, No. 23 (2002) 9-17 (in Polish) 
[8] Wasylewicz O.: The fracture toughness of alloy-nodular cast iron, M.Sc. Thesis, Supervisor: J. Krawczyk, AGH-UST, Kraków, Poland, 2002 (in Polish)

[9] Zajac G.: The influence of heat treatment on mechanical properties of alloy-nodular cast iron, M.Sc. Thesis, Supervisor: J. Krawczyk, AGH-UST, Kraków, Poland, 2001 (in Polish)

[10] Ważny G.: The kinetics of phase transformation of under-cooled austenite of alloy-nodular cast iron, M.Sc. Thesis, Supervisor: J. Pacyna, AGH-UST, Kraków, Poland, 2005 (in Polish)

Received

December 2009 